\title{
PENAMBAHAN RAGI ROTI DAN LAMA FERMENTASI PADA PROSES PENGOLAHAN VIRGIN COCONUT OIL
}

\section{ADDITION OF BAKER YEAST AND FERMENTATION PERIOD IN VIRGIN COCONUT OIL PROCESSING}

\author{
Siti Fathurahmi $^{1}$, Spetriani $^{1 *}$, Asrawaty ${ }^{1}$, Pon Hadi Siswanto ${ }^{1}$ \\ ${ }^{1}$ Program Studi Teknologi Hasil Pertanian, Fakultas Pertanian, Universitas Alkhairaat, \\ Jl. Diponegoro No. 39, Palu 94221, Indonesia
}

\begin{abstract}
ABSTRAK
Salah satu produk olahan buah kelapa adalah Virgin Coconut Oil (VCO) yang diolah pada suhu rendah sehingga kandungan yang penting dalam minyak tetap dapat dipertahankan. Tujuan dari penelitian ini adalah untuk mengkaji pengaruh berbagai penambahan ragi roti dan lama fermentasi pada proses pembuatan VCO terhadap mutu VCO berupa rendemen, kadar air, asam lemak bebas, kejernihan dan penerimaan aroma dan warna VCO. Penambahan ragi roti sebanyak $8 \mathrm{~g}, 10 \mathrm{~g}$, dan $12 \mathrm{~g}$ dengan lama fermentasi 12 jam dan 24 jam. Hasil penelitian menunjukkan bahwa perlakuan penambahan ragi roti 12 g dan lama fermentasi selama 24 jam menghasilkan rendemen terbanyak sebesar $17.73 \%$. Kadar air minyak paling rendah terdapat pada perlakuan $10 \mathrm{~g}$ ragi roti dan lama fermentasi 24 jam. Tingkat kejernihan tertinggi $96.17 \%$ terdapat pada perlakuan ragi roti $12 \mathrm{~g}$ dan lama fermentasi $12 \mathrm{jam}$. Asam lemak bebas terendah pada penambahan ragi roti $8 \mathrm{~g}$ dan lama fermentasi 12 jam. Perlakuan berbagai kadar ragi roti dan lama fermentasi tidak berpengaruh nyata terhadap uji organoleptik baik warna maupun aroma berturut-turut adalah 3,44 (netral) dan 3,44 (netral).
\end{abstract}

Kata kunci: VCO; minyak murni; ragi roti; lama fermentasi

\section{ABSTRACT}

One of the processed coconut product is Virgin Coconut Oil (VCOO which is processed at low temperatures so that the important content in the oil can be maintained. The purpose of this study was to examine the effect of various additions of baker yeast and fermentation period in the VCO processing on the quality of VCO in the yield, moisture content, free fatty acid, clarity and acceptance of odor of VCO and color of VCO. The addition of baker yeast as much as $8 \mathrm{~g}, 10 \mathrm{~g}$, and $12 \mathrm{~g}$ with a fermentation period of 12 hours and 24 hours. The result showed that the addition of $12 \mathrm{~g}$ of yeast baker and 24 hours of fermentation resulted in the highest yield of $17.73 \%$. The lowest water content of oil was found in the treatment of $10 \mathrm{~g}$ of baker yeast and 24 of fermentation period. The highest clarity level of $96.17 \%$ was found in the $12 \mathrm{~g}$ of baker yeast treatment and 12 hours of fermentation period. The lowest free fatty acids are found in the addition of $8 \mathrm{~g}$ of baker yeast and 12 hours of fermentation period. The treatment of various levels of baker yeast and fermentation period did not significantly affect the organoleptic test, both color and odor, respectively, were 3,44 (neutral) and 3,44 (neutral).

Keywords: VCO; virgin coconut oil; baker yeast; fermentation period

\section{Pendahuluan}

Virgin coconut oil (VCO) merupakan bentuk olahan daging kelapa yang saat ini banyak diproduksi masyarakat. Di beberapa daerah, VCO lebih dikenal dengan nama minyak dara, minyak

\footnotetext{
${ }^{*}$ Penulis Korespondensi.

E-mail: spetriani8@gmail.com

Telp: +62-85214000429
}

perawan atau minyak kelapa murni (Setiaji dan Prayugo, 2006). VCO adalah minyak yang berasal dari buah kelapa tua segar yang diolah pada suhu rendah $\left(<60^{\circ} \mathrm{C}\right)$ tanpa proses hidrogenasi dan pemutihan. VCO memiliki struktur kimia yang mengandung ikatan ganda, sehingga tahan terhadap panas, cahaya, oksigen dan proses degradasi. Proses pembuatan VCO agak berbeda dengan cara tradisional. Proses pembuatan VCO dengan cara fermentasi 
dilakukan tanpa perlakuan panas, yaitu dengan penambahan ragi pada krim santan kemudian diinkubasi sampai membentuk lapisan endapan dan lapisan minyak yang ada di permukaan. Beberapa ragi dapat digunakan dalam fermentasi minyak, seperti ragi tape dan ragi roti (Alamsyah, 2005).

VCO memiliki kelebihan terutama karena kandungan asam lauratnya yang tinggi, yaitu sekitar 50-53\%. Asam laurat merupakan medium chain fatty acid (MCFA) yang memiliki nilai nutrisi dan fungsional sangat baik. Hal ini disebabkan karena peran fungsional tersebut menjadikan produk ini semakin populer dan semakin meningkat penggunaannya (Palungkun, 1992). VCO mengandung asam lemak rantai sedang yang mudah dicerna dan dioksidasi oleh tubuh sehingga mencegah penimbunan di dalam tubuh, kandungan antioksidan di dalam VCO pun sangat tinggi seperti tokoferol dan betakaroten. Antioksidan ini berfungsi untuk mencegah penuaan dini dan menjaga vitalitas tubuh (Setiaji dan Prayugo, 2006).

Ciri VCO yang berkualitas baik adalah beraroma khas kelapa, tidak berbau tengik, secara fisik harus jernih dan berwarna transparan seperti kristal. Hal ini mengindikasikan bahwa di dalamnya tidak tercampur dengan bahan lain. Aroma tengik pada minyak kemungkinan diakibatkan oleh proses hidrolisis maupun oksidasi yang terjadi pada minyak. Reaksi hidrolisis akan mengubah minyak menjadi asam lemak bebas dan gliserol. (Sipahelut, 2011). Adanya air dalam minyak dapat menimbulkan reaksi hidrolisis yang akan menimbulkan ketengikan (Aprilasani Zeffa, 2014). Selain itu jika di dalam minyak masih terdapat kandungan air, biasanya akan ada gumpalan berwarna putih. Gumpalan tersebut merupakan komponen protein yang tidak tersaring. Kontaminan seperti ini secara langsung akan mempengaruhi kualitas VCO (Setiaji dan Prayugo, 2006).

Selain kandungan air pada minyak, kualitas VCO juga dapat dinilai dari kandungan asam lemak bebas. Asam lemak bebas atau FFA (free fatty acid) merupakan salah satu parameter yang dapat menunjukkan kerusakan minyak akibat proses hidrolisis oleh adanya interaksi dengan air dan aktivitas lipase (Witono \& Subagio, 2013). Menurut Waisundara et al., (2007) asam lemak bebas merupakan prekursor terjadinya bau tengik akibat hidrolisis, sehingga disimpulkan bahwa semakin rendah asam lemak bebas mengindikasikan kualitas minyak yang dihasilkan semakin baik. Kadar asam lemak bebas yang tinggi akan berpengaruh terhadap mutu produksi minyak, sehingga dapat menimbulkan ketengikan pada minyak dan meningkatnya kadar kolesterol minyak (Sopianti et al., 2017).

Hasil penelitian Meilina et al., (2016) menunjukkan jumlah ragi roti berpengaruh terhadap bilangan peroksida, bilangan iod, bilangan asam, \% free fatty acid (FFA) atau asam lemak bebas dan uji organoleptik aroma VCO yang dihasilkan; sedangkan perbandingan substrat tidak berpengaruh terhadap semua analisis VCO yang dilakukan. Sedang pada penelitian oleh Ngatemin et al., (2013) menunjukan tidak ada pengaruh lama fermentasi terhadap rendemen dan sifat fisik VCO yang meliputi berat jenis dan indeks bias. Lama fermentasi berpengaruh terhadap sifat kimiwai yang meliputi bilangan asam, saponifikasi dan peroksida. Pada uji organoleptik VCO, lama fermentasi mempengaruhi warna dan viskositas tetapi tidak mempengaruhi aroma.

Berdasarkan uraian di atas maka dilakukan penelitian dengan memberikan perlakuan yang berbeda dalam pembuatan VCO menggunakan berbagai ukuran ragi roti dan lama waktu fermentasi, untuk melihat pengaruh penambahan ragi roti dan lama fermentasi terhadap rendemen, kadar air, kejernihan, asam lemak bebas dan penerimaan terhadap aroma dan warna VCO.

\section{Metode Penelitian}

Penelitian dilaksanakan pada Desember 2019- Januari 2021 di laboratorium Analisis Fakultas Pertanian UNISA dan Laboratorium Jurusan Kimia Fakultas MIPA, UNTAD. Bahan utama yang digunakan pada penelitian adalah buah kelapa segar yang sudah tua, air, ragi roti, aquades, etanol, dan $\mathrm{NaOH}$. Peralatan yang digunakan selama penelitian adalah wadah transparan, toples, corong, saringan santan, timbangan digital, selang plastik, pipet tetes, gelas ukur, batang pengaduk, oven, desikator, erlenmeyer, duplo, spektrofotometri.

\section{Analisa Data}

Data hasil penelitian dianalisa menggunakan rancangan faktorial yang terdiri dari dua faktor yaitu penambahan ragi roti dan lama waktu fermentasi. Masing-masing faktor terdiri dari 3 dan 2 taraf, yaitu penambahan ragi roti sebanyak $8 \mathrm{~g}, 10 \mathrm{~g}$, dan $12 \mathrm{~g}$ serta waktu fermentasi 12 jam dan 24 jam. Sehingga 
perlakuan berjumlah 6 dengan kombinasi sebagaimana dalam Tabel 1.

Tabel 1. Jenis perlakuan, kombinasi dan notasi perlakuan

\begin{tabular}{ccc}
\multirow{2}{*}{$\begin{array}{c}\text { Penambahan } \\
\text { Ragi Roti (g) }\end{array}$} & \multicolumn{2}{l}{ Waktu fermentasi (jam) } \\
\cline { 2 - 3 } & $\mathbf{1 2}$ & $\mathbf{2 4}$ \\
\hline 8 & P1 & P4 \\
10 & P2 & P5 \\
12 & P3 & P6 \\
\hline
\end{tabular}

Proses pembuatan VCO menggunakan fermentasi dengan ragi roti diawali dengan penyortiran buah kelapa, pengupasan, pemarutan dan penambahan air dengan perbandingan $1: 1$ hingga diperoleh santan dari buah kelapa tersebut. Diagram alir pembuatan VCO dari santan kelapa ditunjukkan pada Gambar 1.

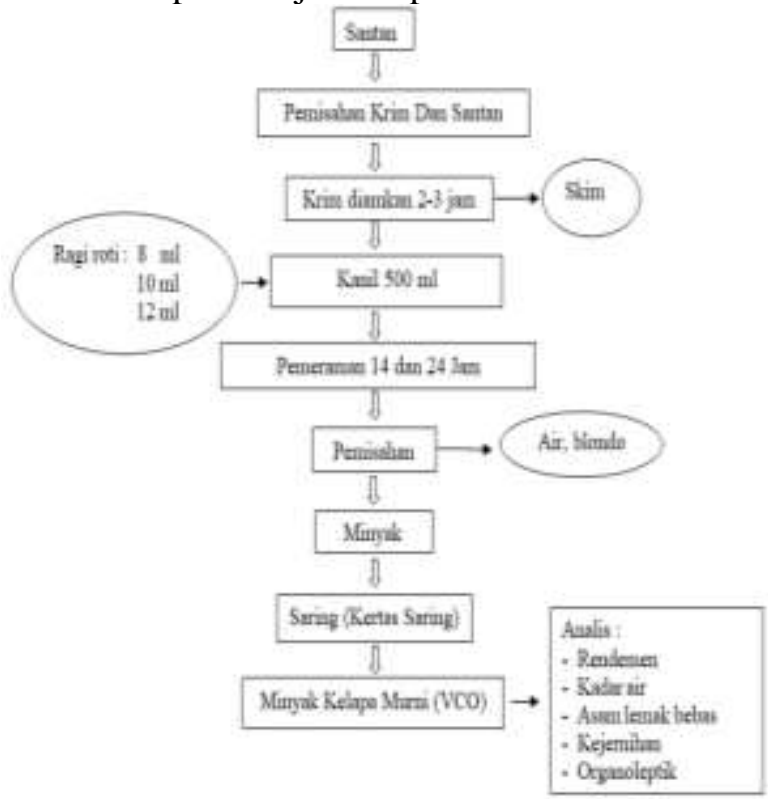

Gambar 1. Diagram alir pembuatan VCO dengan penambahan ragi roti (Sibuea, 2004)

Pengamatan dilakukan terhadap beberapa perubahan pada VCO untuk mengetahui pengaruh perlakuan yang dicobakan. Adapun parameter yang diamati adalah : Rendemen, Kadar Air, Asam Lemak Bebas, Uji Kadar Kejernihan, dan Uji Sensoris.

Penghitungan rendemen dilakukan dengan menggunakan rumus sebagai berikut (AOAC, 1995):

$$
\text { Rendemen }(\%)=\frac{\text { Volume } V C O(\mathrm{ml})}{\text { Volume bahan }(\mathrm{ml})} \times 100 \%
$$

Analisa kadar air (AOAC, 1995) dilakukan dengan menimbang sampel $2 \mathrm{~g}$ kemudian dimasukkan dalam cawan kosong yang telah diketahui beratnya. Cawan tersebut dipanaskan dalam oven selama 2 jam pada suhu $105{ }^{\circ} \mathrm{C}$, selanjutnya didinginkan dalam desikator selama 15 menit, kemudian ditimbang. Cara ini diulangi hingga memperoleh berat konstan. Kadar air dalam bahan dihitung dengan menggunakan rumus

$$
\text { Kadar air }(\%)=\frac{(B S+B C K)-(B C+I)}{B S} \times 100 \%
$$

Asam lemak bebas diukur dengan cara menimbang $30 \mathrm{~g}$ sampel ke dalam erlenmeyer, kemudian $50 \mathrm{ml}$ etanol $95 \%$ netral ditambahkan, 3-5 tetes indikator PP dan titar dengan larutan standar $\mathrm{NaOH} 0,1 \mathrm{~N}$ hingga warna tidak berubah selama 15 detik (tetap merah muda). Lakukan dengan duplo dan dihitung dengan menggunakan rumus

$$
\text { Asam lemak bebas }=\frac{m \times A x n}{n \times 10} \times 100 \%
$$

Uji kadar kejernihan dilakukan dengan melarutkan sampel sebanyak $1 \mathrm{ml}$ dengan aquades menggunakan labu ukur $100 \mathrm{ml}$. selanjutnya dilakukan pengukuran dengan spektrofotometri UVVis pada panjang gelombang $650 \mathrm{~nm}$. Persen transmitan dengan persentase sebesar $90 \%-100 \%$ membuktikan bahwa campuran tersebut memiliki penampakan yang transparan dan jernih (Costa et al., 2012).

Uji organoleptik pada VCO menggunakan panelis tidak terlatih sebanyak 15 orang untuk mengetahui tingkat penerimaan panelis terhadap VCO. Uji aroma dan warna dilakukan dengan menggunakan uji hedonik atau uji kesukaan.

\section{Hasil dan Pembahasan}

Berdasarkan sidik ragam hasil analisa perlakuan berbagai penambahan ragi roti dan lama fermentasi berpengaruh tidak nyata terhadap rendemen VCO yang dihasilkan. Ratarata rendemen VCO pada berbagai perlakuan dapat dilihat pada Gambar 1.

Hasil penelitian menunjukkan bahwa pada perlakuan penyimpanan $12 \mathrm{jam}$, rendemen terbanyak yaitu pada penambahan ragi $8 \mathrm{~g}$ sebanyak $15,53 \%$, sedangkan pada penyimpanan 24 jam, rendemen terbanyak yaitu pada penambahan ragi $12 \mathrm{~g}$ sebanyak $17,73 \%$. 


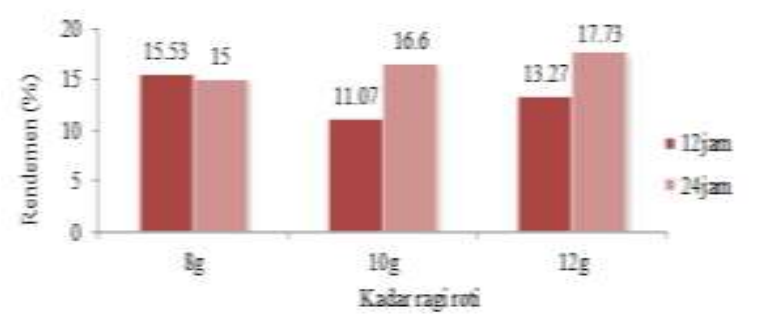

Gambar 1. Rata-rata rendemen VCO pada perlakuan penambahan kadar ragi roti dan lama fermentasi

Perlakuan berbagai kadar ragi roti dan lama fermentasi berpengaruh nyata terhadap kadar air VCO. Rata-rata kadar air VCO dapat dilihat pada Gambar 2.

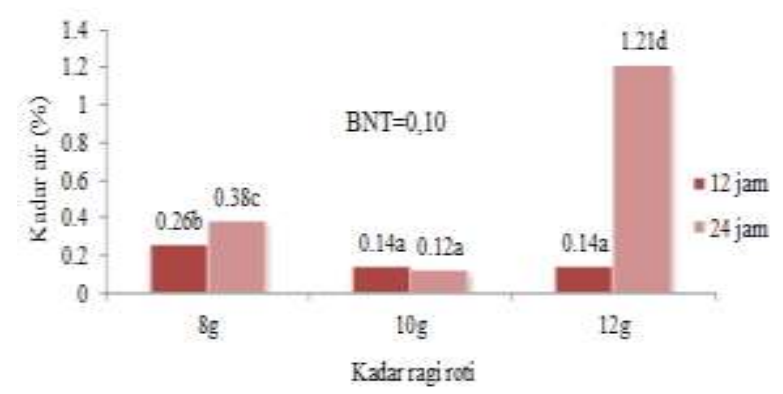

Gambar 2. Rata-rata kadar air VCO pada perlakuan berbagai kadar ragi roti dan lama fermentasi

Hasil penelitian menunjukkan kadar air terendah diperoleh pada perlakuan pemberian ragi roti $10 \mathrm{~g}$ lama fermentasi 24 jam yaitu 0,12 $\%$. Standar mutu kadar air yang sesuai dengan SNI 7381:2008 (BSN, 2008) dan standar mutu virgin coconut oil APCC (Asian Pacific Coconut Community) yaitu antara 0,1 sampai dengan 0,5. Selain itu, menurut Standar Industri Indonesia bahwa kadar air minyak goreng maksimal adalah 0,5\% (Departemen Perindustrian, 1986 dalam Damin $d k k ., 2017)$. Hasil demikian menunjukkan bahwa kadar air VCO yang dihasilkan memenuhi standar industri.

Derajat kejernihan VCO dinyatakan sebagai persen transmitan (\%T). Nilai persentasi transmitan 90-100\% menunjukkan formula tersebut memiliki penampakan bentuk visual yang jernih dan transparan. Semakin tinggi nilai $\% \mathrm{~T}$ semakin jernih penampakan VCO yang diamati (Damin et al., 2017). Perlakuan berbagai kadar ragi roti dan lama fermentasi berpengaruh tidak nyata terhadap kejernihan VCO. Adapun rata-rata kejernihan VCO dapat dilihat pada Gambar 3.

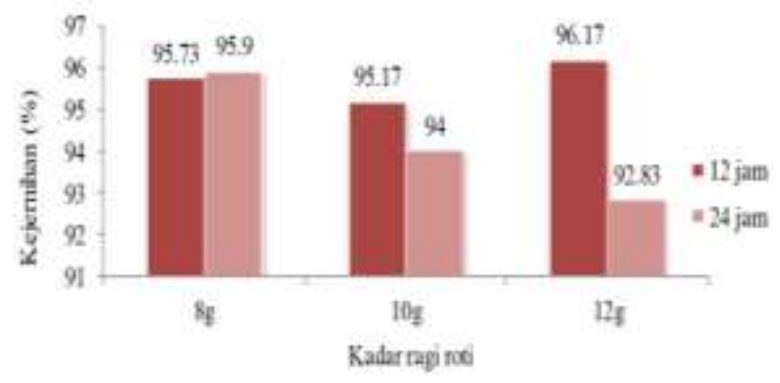

Gambar 3. Rata-rata kejernihan VCO pada perlakuan berbagai kadar ragi roti dan lama fermentasi

Tingkat derajat kejernihan VCO yang diperoleh berkisar antara 92,83\% sampai dengan $96,17 \%$. Derajat kejernihan cenderung lebih tinggi diperoleh pada pemberian ragi roti $12 \mathrm{~g}$ lama fermentasi 12 jam (rata-rata 96.17\%). Kisaran derajat kejernihan tersebut menunjukkan bahwa pemberian ragi roti telah memenuhi uji penentuan persen transmitan, yaitu dengan konsistensi kejernihan mendekati $100 \%$.

Perlakuan berbagai kadar ragi roti dan lama fermentasi berpengaruh nyata terhadap asam lemak bebas VCO. Rata-rata kadar asam lemak bebas VCO dapat dilihat pada Gambar 4.

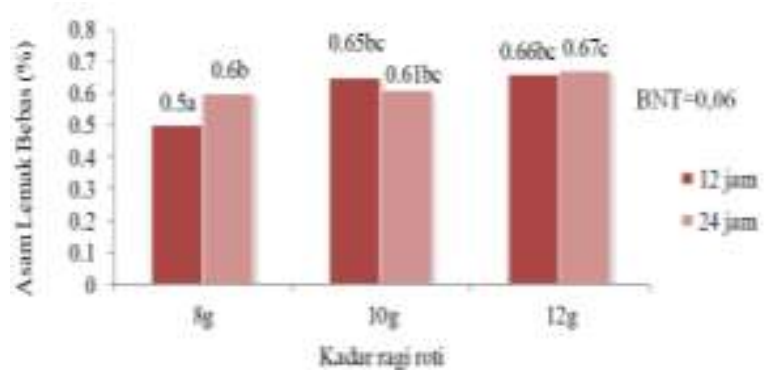

Gambar 4. Rata-rata asam lemak bebas VCO pada perlakuan berbagai kadar ragi roti dan lama fermentasi

Hasil penelitian menunjukkan bahwa kadar asam lemak bebas VCO terendah diperoleh pada perlakuan ragi roti $8 \mathrm{~g}$ dengan lama fermentasi 12 jam yakni 0,5\%. Menurut standar mutu VCO menurut SNI 7381:2008 dan APCC (Asian Pacific Coconut Community) bahwa nilai maksimum kadar asam lemak bebas 0,5\%, sehingga dapat disimpulkan bahwa VCO yang dihasilkan pada perlakuan tersebut memenuhi standar mutu.

Pengujian organoleptik untuk aroma pada VCO hasil penelitian menunjukkan bahwa perlakuan berbagai kadar ragi roti dan lama fermentasi berpengaruh tidak nyata terhadap uji organoleptik aroma VCO. Rata-rata hasil uji 
organoleptik aroma VCO dapat dilihat pada Gambar 5.

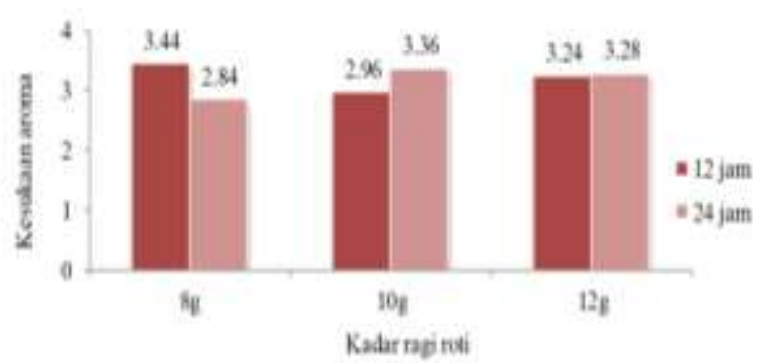

Gambar 5. Rata-rata hasil uji organoleptik aroma VCO pada perlakuan berbagai kadar ragi roti dan lama fermentasi

Aroma suatu bahan pangan seperti minyak kelapa merupakan faktor penting dalam menentukan tingkat penerimaan konsumen. Aroma merupakan hal yang sangat subyektif dan sulit diukur, karena setiap orang memiliki kepekaan dan kesukaan terhadap aroma yang berbeda. Aroma VCO menurut syarat SNI 7381:2008 adalah beraroma khas minyak kelapa dan tidak boleh tengik. Hasil uji organoleptik terhadap aroma VCO cenderung sama pada setiap perlakuan dengan nilai rata-rata 2,84 hingga 3,36 (agak suka). Hal ini mengindikasikan bahwa VCO tersebut memiliki aroma khas minyak kelapa segar, serta tidak berbau tengik.

Uji organoleptik yang dilakukan terhadap warna VCO menunjukkan bahwa perlakuan berbagai kadar ragi roti dan lama fermentasi berpengaruh tidak nyata terhadap uji organoleptik warna VCO. Rata-rata hasil uji organoleptik aroma VCO dapat dilihat pada Gambar 6.

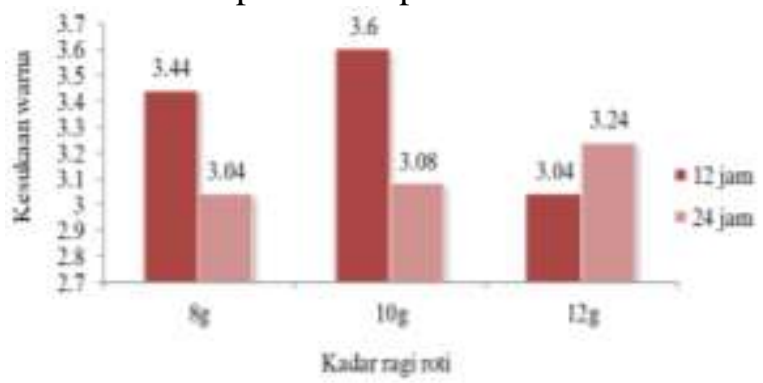

Gambar 6. Rata-rata hasil uji organoleptik warna VCO pada perlakuan berbagai kadar ragi roti dan lama fermentasi

Hasil penelitian pada uji organoleptik terhadap warna VCO cenderung sama pada setiap perlakuan, yakni berkisar antara 3,04 sampai dengan 3,6. Hal ini menunjukkan bahwa VCO yang dihasilkan memiliki sifat warna yang relatif sama, yakni jernih hingga menyerupai air. Hasil uji organoleptik pada warna VCO cenderung lebih tinggi diperoleh pada perlakuan pemberian ragi roti $10 \mathrm{~g}$ dan lama fermentasi 12 jam dengan nilai rata-rata 3,6 (agak suka hingga mendekati suka). Berdasarkan hasil tersebut maka dapat dikatakan bahwa warna VCO yang dihasilkan telah memenuhi syarat standar SNI yang telah ditetapkan, yakin tidak berwarna (jernih).

\section{Kesimpulan}

Rendemen VCO terbaik diperoleh pada perlakuan pemberian ragi roti $8 \mathrm{~g}$ dan lama fermentasi 24 jam yaitu sebesar 16,33. Kadar air terbaik VCO pada perlakuan pemberian ragi roti $10 \mathrm{~g}$ dan lama fermentasi 24 jam yaitu sebesar $0,12 \%$. Kadar kejernihan terbaik terdapat pada perlakuan pemberian ragi roti $12 \mathrm{~g}$ dan lama fermentasi 24 jam dengan nilai sebesar 93,50\%. Kadar asam lemak bebas VCO terbaik diperoleh pada perlakuan ragi roti $8 \mathrm{~g}$ dan lama fermentasi 12 jam yakni 0,51 dan hasil ini telah sesuai dengan standar APCC. Hasil uji organoleptik menunjukkan bahwa aroma dan warna pada VCO dengan perlakuan pemberian ragi roti $8 \mathrm{~g}$ dan lama fermentasi 12 jam dapat diterima panelis dengan nilai rata-rata berturut-turut untuk aroma 3,44 dan warna 3,44 .

\section{Daftar Pustaka}

Alamsyah, Andi Nur. 2005. Virgin Coconut Oil Minyak Penakluk Aneka Penyakit. Agro Media Pustaka. Jakarta AOAC. (1995). Official Methods of Analysis of Association of Official Analytical Chemist. AOAC International. Virginia USA.

APCC. (1996). Coconut Statistical Yearbook 2006. Jakarta: APCC.

Aprilasani Zeffa. (2014). Pengaruh Lama Waktu Pengadukan dengan Variasi Penambahan Asam Asetat dalam Pembuatan Virgin Coconut Oil (VCO) dari Buah Kelapa. Konversi.

BSN, 2008. SNI 73812008: Syarat Mutu Minyak Kelapa Virgin (VCO). (ID). Badan Standarisasi Nasional, Jakarta.

Costa, J. A., Lucas, E. F., Queirós, Y. G. C., \& Mansur, C. R. E. (2012). Evaluation of nanoemulsions in the cleaning of polymeric resins. Colloids and Surfaces A: Physicochemical and Engineering Aspects. https://doi.org/10.1016/j.colsurfa.2012.10.0 11

Damin, S. H., Alam, N., \& Sarro, D. (2017). Karakteristik Virgin Coconut Oil (VCO) Yang Di Panen Pada Berbagai Tempat 
Tumbuh. J Agrotekbis.

Meilina, H., Asmawati, A., \& Moulana, R. (2016). Kajian Penambahan Ragi Roti Dan Perbandingan Volume Starter Dengan Substrat Terhadap Rendemen Dan Mutu Virgin Coconut Oil (Vco). Jurnal Sains Dan Teknologi Reaksi. https://doi.org/10.30811/jstr.v8i1.127

Ngatemin, N., Nurrahman, N., \& Isworo, J. (2013). Pengaruh Lama Fermentasi Pada Produksi Minyak Kelapa Murni (Virgin Coconut Oil) Terhadap Sifat Fisik, Kimia, Dan Organoleptik. Jurnal Pangan Dan Gizi. https://doi.org/10.26714/jpg.4.2.2013.

Palungkun, R. 1992. Aneka Produk Olahan Kelapa. Penebar Swadaya. Jakarta.

Setiaji, B. dan S. Prayugo, 2006. Membuat VCO Berkualitas Tinggi. Penebar Swadaya, Jakarta.

Sipahelut, S. G. (2011). Sifat Kimia dan Organoleptik Virgin Coconut Oil Hasil
Fermentasi Menggunakan Teknik Pemecah Rantai. Jurnal Agroforestri.

Sopianti, D. S., Herlina, H., \& Saputra, H. T. (2017). Penetapan Kadar Asam Lemak Bebas Pada Minyak Goreng. Jurnal Katalisator. https://doi.org/10.22216/jk.v2i2.2408

Waisundara, V. Y., Perera, C. O., \& Barlow, P. J. (2007). Effect of different pre-treatments of fresh coconut kernels on some of the quality attributes of the coconut milk extracted. Food Chemistry. https://doi.org/10.1016/j.foodchem.2006.02. 032

Witono, Y., \& Subagio, A. (2013). Ekstraksi Virgin Coconut Oil Secara Enzimatis Menggunakan Protease dari Tanaman Biduri (Calotropis gigantea). Agritech: Jurnal Fakultas Teknologi Pertanian UGM, 27(3), 100-106. https://doi.org/10.22146/agritech.9597 